\title{
Tropical Pyomyositis: diabetes facilitating the onset of an uncommon disease
}

\section{Piomiosite tropical: diabetes facilitando o aparecimento de uma doença incomum}

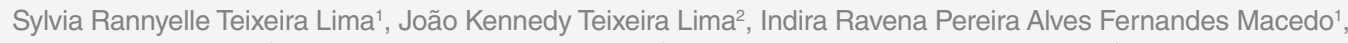

Jaíne Dantas Peixoto1, Débora Laésia Sariava Ribeiro', Maria Mirelle Ferreira Leite Barbosa1,

Márcia Meyrilane de Alencar Aquino ${ }^{1}$, Antonio Leonel de Lima Júnior ${ }^{3}$

${ }^{1}$ Faculdade de Medicina de Juazeiro do Norte (FMJ) - Juazeiro do Norte (CE), Brazil.

${ }^{2}$ Faculdade de Medicina do ABC (FMABC) - Santo André (SP), Brazi

${ }^{3}$ Fundação Oswaldo Cruz (FIOCRUZ) - Rio de Janeiro (RJ), Brazil.

DOI: https://dx.doi.org/10.7322/abcshs.v44i1.1101

\begin{abstract}
Introduction: Tropical pyomyositis is an infectious disease that affects skeletal muscle and may appear as a diffuse inflammation or a rapidly progressive myonecrotic process. The predisposition of this disease in diabetics is already mentioned in several studies. The pathogenesis is possibly related to changes in neutrophils and the reversal of the immune response pattern that occurs in situations such as parasitic diseases. Staphylococcus aureus is the most common microorganism, accounting for $90 \%$ of cases of tropical pyomyositis. The diagnosis is sometimes late because patients usually do not seek care by the first symptoms, and because it is a rare disease and physicians are not very familiar with it. Case report: A 42-year-old male patient with diabetes mellitus, hypothyroidism, anemia, thrombocytopenia, and hypoalbuminemia developed tropical pyomyositis with multiple muscle abscesses in quadriceps, soleus and anterior tibial, triceps and biceps brachialis and pronator round, requiring prolonged antibiotic therapy and surgical drainage. Conclusion: Pyomyositis is a little known disease and if not diagnosed early can be fatal.
\end{abstract}

Keywords: Pyomyositis; abscess; Staphylococcal infections.

\section{RESUMO}

Introdução: A piomiosite tropical é uma doença infecciosa que afeta o músculo esquelético, aparecendo como uma inflamação difusa ou um processo mionecrótico rapidamente progressivo. A predisposição desta enfermidade em diabéticos já é referida em vários estudos. A patogênese possivelmente está relacionada a alterações nos neutrófilos e na inversão do padrão de resposta imune que acontece em situações como parasitoses. Staphylococcus aureus é o microorganismo mais comum, representando $90 \%$ dos casos de piomiosite tropical. O diagnóstico pode ser tardio porque os pacientes geralmente não buscam cuidados com os primeiros sintomas e, por ser uma doença rara, pode surpreender um médico ainda não familiarizado com esta entidade clínica. Relato de caso: Paciente do sexo masculino com 42 anos de idade com diabetes mellitus, hipotireoidismo, anemia, trombocitopenia e hipoalbuminemia que desenvolveu piomiosite tropical com múltiplos abscessos musculares em quadríceps, sóleo e tibial anterior, tríceps e bíceps braquial e pronador redondo, necessitando de antibioticoterapia prolongada e drenagem cirúrgica. Conclusão: A piomiosite não é uma doença bem conhecida e pode ser fatal se não for diagnosticada precocemente.

Palavras-chave: piomiosite; abscesso; infecções estafilocócicas.

Received on: 02/01/2018

Revised on: $05 / 05 / 2018$

Approved on: $07 / 23 / 2018$

Corresponding author: Sylvia Rannyelle Teixeira Lima - Faculdade de Medicina de Juazeiro do Norte - Avenida Tenente Raimundo Rocha, 555 - Cidade Universitária - CEP: 63040-360 - Juazeiro do Norte (CE), Brazil - E-mail: sylviarannyelle@hotmail.com

Conflict of interests: nothing to declare. 


\section{INTRODUCTION}

The first reports of pyomyositis date from 1852, by Virchow, and later by Scriba, in 1885. In Brazil the first reports of cases were in 1866 by Salvia, in Rio de Janeiro. This disease is predominant in tropical regions, with recent incidence increases in temperate regions ${ }^{1,2}$.

Under normal circumstances skeletal muscle tissue is intrinsically resistant to bacterial infections. In tropical pyomyositis, the microorganisms reach the skeletal muscles during a transient bacteremia, finding favorable conditions and triggering the infection ${ }^{3,4}$.

The microorganism most commonly found is Staphylococcus aureus, appearing in about $90 \%$ of cases in tropical areas and $60 \%$ in non-tropical regions ${ }^{5}$.

Tropical pyomyositis usually affects individuals with some immunological deficiency, becoming an important complication among those affected by the human immunodeficiency virus (HIV), which is facilitated by the infection itself, antiretroviral therapy, or infections caused by parasites and mycobacteria ${ }^{6}$.

The tropical disease occurs in all age groups with a peak incidence in two of them, 2 to 5 years and 35 to 40 years, with a male to female ratio of $4: 1$. The non-tropical disease presents a peak of 30-50 and 60-70 years, with a 3:1 ratio ${ }^{1}$. This pattern is also found in the northern region of Brazil, especially in the states of Amazonas and Acre ${ }^{2}$.

Tropical pyomyositis is a disease that is still little known. Its initial characteristics are nonspecific and can be easily confused with other more prevalent pathologies, including arboviruses. The delay in recognition results in a greater number of exams, interventions and days of hospitalization, generating high costs. Besides, it negatively influences the prognosis, raising the risk of sequelae or death.

The objective of the report is to describe the case of a diabetic's patient who was hospitalized with tropical pyomyositis at a tertiary hospital in the municipality of Juazeiro do Norte, in the northeast of Brazil, and to stress the importance of their early recognition as well as the rapid institution of treatment.

\section{CASE REPORT}

The information contained in this study was obtained through a review of medical records and related literature. The data were only obtained after approval of the Ethics Committee in Research and the signing of the secrecy Term of the medical record.

Male patient aged 43 years, white, obesity grade 2, married, from northeast of Brazil, a region of tropical climate, with diabetes mellitus, hypertension and hypothyroidism diagnosed for approximately 3 years, using levothyroxine $125 \mu \mathrm{g}$, metformin $500 \mathrm{mg}$ / day, enalapril $20 \mathrm{mg} /$ day and simvastatin $40 \mathrm{mg} /$ day. The patient reported asthenia and diffuse myalgia, beginning 15 days prior to admission, without association with other signs or symptoms, obtaining partial improvement with analgesics. The next day, evolved with increased pain in the lower limbs, more prominent on the left, radiating to the ipsilateral gluteal region, making it difficult to ambulate and not responsive to usual analgesics. One day after hospitalization, the patient reported worsening of pain and presence of knee and elbow edema, both on the right. On the third day, from the beginning of the clinical condition, the patient could not walk due to pain (Analog Visual Scale: 10).

In the physical examination the general health was normal, afebrile, normal blood pressure, capillary glycemia $180 \mathrm{mg} / \mathrm{dl}$ Cardiac and respiratory evaluation without changes: 1) Right lower limb: with edema, painful to digitopression in the leg and thigh region, with hyperemia, increased limb temperature and difficulty in knee and hip movement; 2) Lower left limb: with edema in the calf, with increase in temperature to the touch, hyperemia and pain the digitopressão and movement of the foot; 3) Right upper limb: semi-flexed limb with extension of elbow extension due to pain, with edema, temperature increase, digitopression pain and hyperemia in the joint region; 4) Upper left limb: with edema, increased temperature in the region of the elbow joint, without movement limitation.

The first conduct was to puncture the right knee for removal of purulent contents, requiring surgical drainage of the join. The drainage was interrupted after $24 \mathrm{~h}$ due to the absence of flow through the drain. Antibiotic therapy was started with ceftriaxone $2 \mathrm{~g} \mathrm{24/24} \mathrm{h}$ and oxacillin $2 \mathrm{~g} \mathrm{4/4} \mathrm{h,} \mathrm{with} \mathrm{hospital} \mathrm{admission.} \mathrm{The}$ antibiotic therapy was chosen empirically, based on the sensitivity profile of the community bacteria, and considering the diagnostic hypothesis of septic arthritis, giving coverage to gram negative and gram positive germs.

In view of the extension of the clinical condition it was realized some investigation through images of the inflammatory foci, and multiple muscle abscesses were visualized. The images were available in the medical record, only the reports of the examinations. Early nuclear magnetic resonance was not feasible due to intense pain to the positioning, even with medication, being initially performed only ultrasonography and one week after the magnetic resonance imaging.

After one week of use of ceftriaxone and oxacillin, no improvement in pain and/or reduction of edema/inflammation was observed, and meropenem $1 \mathrm{~g} \mathrm{8/8} \mathrm{h}$ and vancomycin $1 \mathrm{~g} \mathrm{12/12 \textrm {h }}$ were started, due to lack of clinical response. The results of the blood cultures were negative, preventing guided antibiotic therapy. The result of the drained pus culture was positive for methicillin-sensitive S. aureus, but there was no good clinical response to the therapy instituted initially, even with favorable in vitro sensitivity profile.

Conservative treatment with the new antibiotic regimen was maintained for another month. A significant reduction of 
abscesses in the upper limbs was observed, but an unsatisfactory response was obtained in the reduction of abscesses in the gluteus and left trochanter and right thigh, and a surgical approach to drainage was necessary.

Antibiotic therapy was prolonged, totaling three months, when a complete reduction of all abscesses and infiltrative procedures were obtained and the patient was discharged.

\section{DISCUSSION}

By analyzing the case, we observe that there was no history of recent trauma, which would fit as the entry point of the infection. Transthoracic echocardiography was performed to exclude the formation of emboli due to bacterial endocarditis.

Search for autoimmune disease was started after finding antinucleus factor and reagent chromosomal metaphase plate with a title of 1/1280 - homogeneous nuclear pattern, splenomegaly, thrombocytopenia values $46000 \mathrm{U} / \mathrm{L}$ (reference values: 150,000 a $450,000 \mathrm{U} / \mathrm{L}$ ) prior to the diagnosis. This last investigation was not conclusive until the moment of hospital discharge, being referred to outpatient follow-up. An investigation was made for systemic lupus erythematous, but the patient did not meet the diagnostic criteria and remained in clinical follow-up to anticipate the diagnosis in case of later manifestation. In relation to thrombocytopenia there was an improvement in laboratory levels even during hospitalization. In addition, the patient had anemia (hemoglobin $11.3 \mathrm{~g} / \mathrm{dL}$, reference value: 13.5-18) and hypoalbuminemia (1.34 g/dL, reference value: 4.01-4.78 g/dL) (Table 1).

At the beginning of the clinical picture, mainly considering local epidemiology, myalgia and asthenia were easily associated with arboviruses, such as chikungunya and dengue; the absence of fever could be explained by being a diabetic patient. With the worsening of the edema and pain in the knee, and after puncture of suppurative content, the hypothesis of septic arthritis was pertinent, but this diagnostic hypothesis was disregarded after imaging showed that there was communication of the knee joint with the abscesses located in the distal region of the quadriceps muscle. This aspect was also observed in the right elbow joint with abscesses located in biceps and triceps brachii. From the amplification of research with imaging examinations, which showed the multiple abscesses, it was possible to confirm that it was a case of tropical pyomyositis. Doppler ultrasonography was performed on the lower limbs to rule out superficial or deep venous thrombosis. There was no evidence of abdominal disease.

At the time of diagnosis the patient was in the second stage of the disease - suppurative stage - there were signs of inflammation accentuated with tension added to muscular edema, 10.800

Table 1: Laboratory tests

\begin{tabular}{|c|c|c|c|}
\hline TEST & RESULT & TEST & RESULT \\
\hline Hemoglobin & $11.3 \mathrm{~g} / \mathrm{dL}$ & Amylase & $74 \mathrm{U} / \mathrm{L}$ \\
\hline Hematocrit & $33.4 \%$ & Lipase & $28,7 \mathrm{U} / \mathrm{L}$ \\
\hline Leukocytes & $10800 / \mathrm{mm}^{3}$ & Total cholesterol & $86 \mathrm{mg} / \mathrm{dL}$ \\
\hline Segmented & $86 \%$ & Lactate & $2.9 \mathrm{U} / \mathrm{L}$ \\
\hline Bats & $6 \%$ & Direct Coombs & Negative \\
\hline Monocytes & $6 \%$ & Anti-HIV & Negative \\
\hline Typical/atypical lymphocytes & $7 \% / 0$ & Dengue (enzyme immunoassay) & Non-reactive \\
\hline Platelets & $46,000 \mathrm{U} / \mathrm{L}$ & PTH & $8.10 \mathrm{pg} / \mathrm{mL}$ \\
\hline Sodium & $113 \mathrm{mE} / \mathrm{L}$ & TSH & $66.17 \mathrm{mlU} / \mathrm{L}$ \\
\hline Potassium & $3.3 \mathrm{mE} / \mathrm{L}$ & Free T4 & $0.41 \mathrm{ng} / \mathrm{dL}$ \\
\hline CRP & $41.85 \mathrm{mg} / \mathrm{dL}$ & Anti-thyroglobulin antibodies & $2.6 \mathrm{IU} / \mathrm{mL}$ \\
\hline ESR & 105 mm/h & Anti-HCV antibodies & Non-reactive \\
\hline Urea & $58.9 \mathrm{mg} / \mathrm{dL}$ & Anti-HBs / Anti-HBc IgM / HBs Ag & Non-reactive \\
\hline Uric acid & $5.2 \mathrm{mg} / \mathrm{dL}$ & Rheumatoid factor & $8.6 \mathrm{UI} / \mathrm{mL}$ \\
\hline Creatinine & $1.14 \mathrm{mg} / \mathrm{dL}$ & American visceral leishmaniasis & Negative \\
\hline Albumin/globulin ratio & 0.2 & FAN - Anti-metaphase and anti-core plate & Reagent (title - 1/1280) \\
\hline Albumin & $1.34 \mathrm{~g} / \mathrm{L}$ & Anti-SM antibodies & $<0.1 \mathrm{U} / \mathrm{dL}$ \\
\hline Hemoculture (2 samples) & Negative & C3 & $188 \mathrm{mg} / \mathrm{dL}$ \\
\hline Transferrin & $80 \mathrm{mg} / \mathrm{Dl}$ & C4 & $23.9 \mathrm{mg} / \mathrm{dL}$ \\
\hline Transferrin saturation index & $20 \%$ & $\mathrm{CH} 50$ & Iow (<60 U CAE) \\
\hline Ferritin & $974.76 \mathrm{ng} / \mathrm{mL}$ & Anti-cardiolipin IgG/IgM antibodies & Non- reactive \\
\hline Iron & $29 \mu \mathrm{g} / \mathrm{dL}$ & Lupus anticoagulante antibodies & $<1.2$ \\
\hline Total iron binding capacity & $145 \mu \mathrm{g} / \mathrm{dL}$ & Anti-parietal cell antibodies & Non-reactive \\
\hline Folic acid & $5.05 \mathrm{ng} / \mathrm{mL}$ & B12 vitamin & $1,342.1 \mathrm{pg} / \mathrm{mL}$ \\
\hline Insulin & $14.8 \mu \mathrm{U} / \mathrm{mL}$ & Peptide C & $3.4 \mathrm{ng} / \mathrm{mL}$ \\
\hline
\end{tabular}

Legend: CRP - C reactive protein; ESR - erythrocyte sedimentation rate; PTH - Parathormone; TSH - thyroid stimulating hormone; AC-antibody; FAN - anti-nuclear factor; HIV - human immunodeficiency virus; HCV - Hepatitis C Virus; HB - Hepatitis B; C3 - Complement 3; C4 - Complement 4; CH50 - Total Complement 50; Ag - antigen; Ig - immunoglobulin; SM - Smith. 
leukocytes (reference value: 4,000 to 10,000 ) (Table 1), unlike the typical clinical presentation, absence of fever. Blood culture was negative. The muscular biopsy was dispensed by the clinical characteristics of the patient, which left no doubt as to the diagnosis.

Our patient required repeated surgical drainage along with broad-spectrum antibiotics for extended time (12 weeks), insulin, levothyroxine adjustment, and supportive measures to control infection.

The pathogenesis of pyomyositis is not fully understood. The literature reports of blunt trauma, in which there is extravasation of blood into the muscle, or vigorous exercise of the involved muscle groups are reported in $20-50 \%$ of the cases of pyomyositis ${ }^{7}$. The theory that associates pyomyositis with muscular stress is well accepted when the affection is restricted to a single muscle group, but when there is involvement of several muscle groups, another explanation must be given ${ }^{8}$.

In immunologically competent individuals, in the occurrence of bacteremia and muscular stress, there is localized bacterial colonization, which may be associated with a viral infection, parasitic or nutritional deficiency. There is a predisposition to pyomyositis in neutropenic individuals or with qualitative defects of the function of these cells and parasitic diseases. According to Lambertucci et al. ${ }^{9}$, there is a change in the Th1 immune response pattern for a Th2 response in parasites, with an increase in Ig E concentration and a change in cytokine expression, a fact that may compromise the response to fungi and bacteria. This relationship was extensively described by Damian et al. ${ }^{10}$ and Rayes et al. ${ }^{11}$ in studies in the states of Acre and Amazonas, northern region of Brazil, associating pyomyositis with human toxocariasis.

It has also been suggested that an abnormality of the immune system may be an underlying cause in many cases, especially by the inadequate action of T lymphocytes against staphylococcus. Some people may be colonized by $S$. aureus, but because they have an active immune system, they are not affected by the transient presence of this organism in the bloodstream ${ }^{12}$.

Among immunity modifying factors, there were diabetes mellitus which may be involved as facilitators of the spread of the infection. There is no formal link between diabetes and pyomyositis, but it is widely reported in literature the high incidence of pyomyositis in patients with diabetes. An interesting fact to consider is the increase in cases of pyomyositis in this population, which increased from $8 \%$ in studies between 1971-1991 to 31\% in the most current studies ${ }^{12}$.

In diabetics, the predisposition to infections occurs primarily in individuals with longstanding disease and with a lack of glycemic control. Damage to the humoral and cellular defense system, combined with damage to the nerves and blood vessels, can act as facilitators of infectious entities. Malnutrition is another important factor for the development of pyomyositis ${ }^{13}$.
Anemia and hypoproteinemia (hypoalbuminemia) were seen in a significant proportion of patients in studies in India ${ }^{14}$. The diagnosis is sometimes late because patients usually do not seek care for the first symptoms, and because it is a rare disease, doctors are still not familiar with the entity. The differential diagnosis depends on the region and includes osteomyelitis, deep venous thrombosis, cellulitis, hematoma, tumors, synovitis, septic arthritis and, for iliopsoas pyomyositis, appendicitis, diverticulitis and other causes of peritonitis ${ }^{12}$.

Pyomyositis usually presents as a skeletal muscle infection, but also appears as a diffuse inflammation or a rapidly progressive myonecrotic process. Although any skeletal muscle may be involved, the disease has a predilection for large muscles in the body. The most commonly involved site is the quadriceps muscle (65\%), followed by the gluteal muscles (35\%). The involvement of several muscles occurs in $12-60 \%$ of the pyomyositis $^{3}$. The possible reason for involvement of the pelvic girdle and lower extremity muscles may be the greater degree of movement, which may cause subclinical trauma to the muscles making them susceptible ${ }^{1}$. Overall results are satisfactory if the disease is recognized and treated in the early stages. Late stages present an increased morbidity and prolonged hospitalization, which may result in local extension to adjacent bone or junction, may cause a compartment syndrome, a remote infection such as pericarditis, endocarditis, myocarditis, pulmonary and cerebral abscesses, renal failure, septicemia, and even death. Mortality ranged from $0.5 \%$ to $2 \%$.

According to Larkin et al. ${ }^{5}$, the clinic will depend on the stage presented by the patient at the time of the investigation, this classification is valid for tropical and non-tropical pyomyositis, whose differentiation is only geographical $\left.{ }^{4,5}: 1\right)$ First stage, the so-called "invasive stage", only $2 \%$ of patients. It lasts about ten days and the signs of inflammation are minimal. Patients present muscle pain, fever, leukocytosis and elevation of erythrocyte sedimentation rate. Other findings may be anemia and eosinophilia; 2) The second is the "suppurative stage". Usually this phase is between 10 and 21 days after the onset symptoms. More than $90 \%$ of patients present at this stage. Signs of inflammation are most accentuated with muscle tension and edema, fever and leukocytosis; 3 ) The third stage is the "final stage". The patient is actually sick with high fever, toxicity and occasionally septicemia and coma can be found. About $5 \%$ of patients are presented at this stage.

Atypical presentation may occur in patients with co-morbid conditions such as immunodeficiency virus (HIV) infection, diabetes mellitus, hematopoietic disorders, and other conditions that occur with defective neutrophilic function ${ }^{15}$. Blood cultures are positive only in 5\% of cases, whereas in non-tropical cases septicemia has been reported more frequently in about one third of patients ${ }^{3}$. 
The diagnosis of pyomyositis is often difficult due to the lack of specific clinical features. They also overlap with symptoms with common endemic febrile diseases, making clinical suspicion often low. Generally, leptospirosis, malaria, dengue, other viral fevers, polymyositis, septic arthritis, osteomyelitis, cellulitis, lymphangitis, deep vein thrombosis should be considered as differential diagnosis ${ }^{14}$. For diagnosis the culture of the abscess or muscle biopsy can be performed ${ }^{3}$.

Once diagnosed, pyomyositis requires early institution of antibiotics and an evaluation for surgical drainage. Antistaphylococcal medication is traditionally the medicine of choice; broad-spectrum antibiotic coverage for anaerobic infections, especially in patients without immune compromise. With the emergence of drug resistance, the right choice of antibiotics would significantly improve outcome ${ }^{14}$. The duration of treatment is until the complete reduction of abscesses, normal leukocytes and absence of febrile for at least one week. If the patient presents a late phase with secondary dissemination of infection of the involved muscles, the recommendation is four to six weeks of parenteral antimicrobial therapy ${ }^{15}$.

Clinical, the immunosuppressive state of diabetes and the knowledge about pyomyositis made possible the early diagnosis and the institution of adequate therapy, so that the disease did not progress into more serious and easily fatal levels. Even with prolonged hospitalization the patient did not present deformities in the affected joints and followed with complete improvement of condition.

\section{REFERENCES}

1. Chattopadhyay B, Mukhopadhyay M, Chatterjee A, Biswas PK, Chatterjee N, Debnath NB. Tropical Pyomyositis: a single-institutional experience of 12 cases. N Am J Med Sci. 2013;5(10):600-3. http://dx.doi.org/10.4103/1947-2714.120796

2. Rayes AA, Lambertucci JR. A associação entre a toxocaríase humana e os abscessos piogênicos. Rev Soc Bras Med Trop. 1999;32(4)425-38. http://dx.doi.org/10.1590/S0037-86821999000400014

3. Chauhan S, Jain S, Varma S, Chauhan SS. Tropical pyomyositis (myositis tropicans): Current perspective. Postgrad Med J. 2004;80:267-70.

http://dx.doi.org/10.1136/pgmj.2003.009274

4. Christin L, Sarosi GA. Pyomyositis in North America: case reports and review. Clin Infect Dis.1992;15(4):668-77. http://dx.doi.org/10.1093/clind/15.4.668

5. Larkin JA, Shashy RG, Poblete SJP. Nontropical pyomyositis. Hosp Phys. 1999;67-71.

6. Siqueira NG, Siqueira CMVM. Piomiosite tropical. Rev Col Bras Cir. 1998;25(3):205-7. http://dx.doi.org/10.1590/S0100-69911998000300010

7. Navinan MR, Yudhisdran J, Kandeepan T, Kulatunga A. Tropical pyomyositis as a presenting feature of subclinical leukemia: a case report. J Med Case Rep. 2015;9:39. http://dx.doi.org/10.1186/s13256-015-0513-z

8. Gibson RK, Rosenthal SJ, Lukert BP. Pyomyositis increasing recognition in temperate climates. Am J Med. 1984;77(4):768-72. https://dx.doi.org/10.1016/0002-9343(84)90383-8
9. Lambertucci JR, Rayes AA, Serufo JC, Nobre V. Pyogenic abscesses and parasitic diseases. Rev Inst Med Trop. 2001;43(2):63-74

http://dx.doi.org/10.1590/S0036-46652001000200003

10. Damian MM, Monteiro A, Malheiro A, Souza LO, Monte RL, Tavares AM. Piomiosite tropical e associação com Toxocara spp: Aspecto clínico laboratorial e gravidade em 116 casos. Rev Panam Infectol. 2015;17(1):13-20.

11. Rayes AA, Nobre V, Teixeira DM, Serufo JC, Brasileiro Filho $\mathrm{G}$, Antunes $\mathrm{CM}$, et al. Tropical pyomyositis and human toxocariasis: a clinical and experimental study. Am J Med. 2000;109(5):422-5.

https://doi.org/10.1016/S0002-9343(00)00512-X

12. Seah MY, Anavekar SN, Savige JA, Burrell LM. Diabetic pyomyositis: an uncommon cause of a painful leg. Diabetes Care. 2004;27(7):1743-4.

https://dx.doi.org/10.2337/diacare.27.7.1743

13. Pozzilli P, Leslie RD. Infections and diabetes: mechanisms and prospects for prevention. Diabet Med. 1994:11(10):935-41. https://doi.org/10.1111/j.1464-5491.1994.tb00250.x

14. Malhotra P, Singh S, Sud A, Kumari S. Tropical pyomyositis: experience of a tertiary care hospital in north-west India. J Assoc Physicians India. 2000;48(11):1057-60.

15. Lemonick DM. Non-tropical pyomyositis caused by methicillinresistant Staphylococcus aureus: an unusual cause of bilateral leg pain. J Emerg Med. 2012;42(3):e55-62. https://doi.org/10.1016/j.jemermed.2008.12.020 